\title{
Characterization of Some Rhizobium Isolates and Their Effectiveness on Pea
}

\author{
M Solaiman Talukder ${ }^{1}$, ARM Solaiman ${ }^{1 *}$, Delowara Khanam² and M Golam Rabbani ${ }^{1}$ \\ ${ }^{1}$ Department of Soil Science, Bangabandhu Sheikh Mujibur Rahman Agricultural University (BSMRAU), Salna, Gazipur 1706, Bangladesh, ${ }^{2}$ Division \\ of Soil Science, Bangladesh Agricultural Research Institute (BARI), Joydebpur, Gazipur 1701, Bangladesh
}

[Received 30 January 2008; Accepted 14 June 2008]

\begin{abstract}
Six isolates of Rhizobium were isolated from pea (Pisum sativum) to characterize their cultural properties and observe their effectiveness on host legume. In a laboratory study Rhizobium isolates showed characteristic pattern of reactions in respect of growth rate, colony characteristics and acid/alkali production on different growth media. The effect of inoculations of Rhizobium isolates on nodulation, growth and nitrogen fixation of pea were assessed by a pot experiment on a clay loam soil of Bangabandhu Sheikh Mujibur Rahman Agricultural University, Gazipur. Inoculation treatments comprised of Rhizobium isolates $R_{1}, R_{2}, R_{3}, R_{4}, R_{5}$ and $R_{6}$. Among the Rhizobium isolates $R_{3}$ and $R_{5}$ of pea at $50 \%$ flowering stage had significant positive effective on nodulation, growth and nitrogen fixation of pea. There were high positive correlations among the number and dry weight of nodules, $\mathrm{N}$ content and uptake by shoot of pea.
\end{abstract}

Keywords: Rhizobium, Pea, Nodulation, Growth, Nitrogen fixation

\section{Introduction}

Pea (Pisum sativum) is one of the main grain legume crops in Bangladesh. It is a high protein content food crop. As pea is a short durable crop. Its cultivation is highly profitable and preferable to the farmers. In Bangladesh, only 17,192 ha of land is under pea cultivation where its production is $13,735 \mathrm{MT}$, which is lower than other vegetables ${ }^{1}$. Inclusion of peas in crop rotation helps improvement of soil fertility and yield of the succeeding crops $^{2}$. Pea like other legumes is capable of fixing and utilizing atmospheric nitrogen through symbiotic relationship with Rhizobium bacteria at the root of the crop.

Rhizobium inoculants significantly improves yield in many leguminous crops and can minimize the use of synthetic nitrogenous fertilizer, which is rather expensive and causes injury to soil properties ${ }^{3}$. The crop thus improves soil and economizes crop production not only for itself but also for the next cereals or non-legume crops grown in the relation and there by reducing the requirement of added nitrogen fertilizers. Many researchers ${ }^{4-10}$ have reported the beneficial effects of inoculation of grain legumes. Seed inoculation with Rhizobium strains is known to influence nodulation and growth of pea ${ }^{11}$. It was observed that the maximum green pod yield of $30.78 \mathrm{~g} / \mathrm{plant}$ ( $115 \%$ increase over uninoculated control) and mature seed yield of 5.10 g/plant (86\% increase over uninoculated control) were obtained when seeds of pea were inoculated with Rhizobium inoculant ${ }^{12}$. Most soils of Bangladesh contain appreciable number of ineffective Rhizobium strain. But the number of Rhizobium strains effective on pea is very scarce in soils of Bangladesh.
Keeping these facts in mind the present investigation was, therefore, carried out to characterize some Rhizobium strain isolated from root nodules and to assess their effectiveness in respect of nitrogen fixation in pea.

\section{Materials and Methods}

A laboratory experiment was conducted to characterize six Rhizobium isolates recovered from nodules of pea collected from Jessore, Ishourdi (agro-ecological zone, AEZ 11), Faridpur, Rajbari (AEZ 12) and Barisal (AEZ 13) districts. Plants of pea were selected randomly from farmers' field of the respected AEZs. Nodules separated from roots of pea were washed in fresh water and preserved in vial containing silica gel. Silica gel was used to soak the water of the nodules that might cause rotting of the nodules. The collected nodules were surface sterilized by exposing them to $95 \%$ alcohol for $5-10$ sec. Then the nodules were immersed in $0.1 \%$ acidified mercuric chloride for 3-4 min. These nodules were then washed with six changes of sterile water. The nodules were then crushed and streaked on YEM agar medium.

YEM agar medium contained the following constituents: $\mathrm{K}_{2} \mathrm{HPO}_{4}$ (0.5 g), $\mathrm{MgSO}_{4} \cdot 7 \mathrm{H}_{2} \mathrm{O}(0.2 \mathrm{~g}), \mathrm{NaCl}(0.2 \mathrm{~g}), \mathrm{CaCO}_{3}(0.2 \mathrm{~g}), \mathrm{FeCl}_{3} \cdot 6 \mathrm{H}_{2} \mathrm{O}$ ( $0.01 \mathrm{~g})$, mannitol (10 g), yeast extract ( $0.4 \mathrm{~g})$, agar (Difco, USA) (15 g), deionized water to 1 litre was used. The $\mathrm{pH}$ of the medium was adjusted to 7.0 with $\mathrm{HCl}$ solution. The medium was inoculated with the Rhizobium strains and incubated for one week. Colonies of the strains developed on the medium observed for their morphology and appearance. The YEM agar medium containing bromothymol blue indicator ${ }^{13}$ was used for identification of strains. The reaction of the rhizobial strains on this medium was 
noted every week. Fast-growing rhizobial strains produce acid in this medium, turning the medium yellow and slow growing rhizobia produce alkali, which turns the medium blue $\mathrm{e}^{13 .}$

Rhizobium isolates collected from Faridpur were designated as $\mathrm{R}_{1}, \mathrm{R}_{2}$ and $\mathrm{R}_{3}$, those from Rajbari as $\mathrm{R}_{4}$ and $\mathrm{R}_{5}$ and that from Ishsurdi as $R_{6}$. The isolates were assessed for colony characteristics, growth rate and acid/alkali production in laboratory media with a view to know their basic properties prior to more intensive study on their performance in respect of nodulation, growth, nitrogen fixation of pea.

A pot experiment was conducted at Bangabandhu Sheikh Mujibur Rahman Agricultural University, Gazipur to study the effect of Rhizobium isolates on nodulation, growth and nitrogen fixation of pea. The soil used in this experiment belongs to Salna series under Madhupur tract (AEZ 28). The collected soil samples were air-dried, crushed and passed though an mm sieve. Then the soil was autoclaved at $121^{\circ} \mathrm{C}$ for $1 \mathrm{~h}$ to destroy the indigenous organisms inhabiting there in. The soil was clay loam texture and contained $0.61 \%$ organic carbon, $0.05 \%$ total nitrogen, $0.07 \%$ available phosphorus (P), 0.84 (meq/100 g dry soil) exchangeable potassium (K), 13.75 (meq/100 g dry soil) cation exchange capacity (CEC) and had a pH 7.1. Pea seeds were collected from Bangladesh Agricultural Research Institute, Joydebpur, Gazipur. The seeds were healthy, vigorous, well matured and free from other materials.

The experiment was laid out in a randomized complete block design (RCRD) with four replications. The treatments were arranged in the experimental units randomly. Inoculation treatments included uninoculated control $\mathrm{R}_{0}$, Rhizobium isolate $\mathrm{R}_{1}$, Rhizobium isolate $\mathrm{R}_{2}$, Rhizobium isolate $\mathrm{R}_{3}$, Rhizobium isolate $\mathrm{R}_{4}$, Rhizobium isolate $\mathrm{R}_{5}$, and Rhizobium isolate $\mathrm{R}_{6}$. Each pot was filled with $1 \mathrm{~kg}$ of soil. Basal doses of phosphorus (P), potassium (K), zypsum (S), molybdenum (Mo) at the rate of $50 \mathrm{~kg} \mathrm{P}_{2} \mathrm{O}_{5}$ /ha (in the form of triple superphosphate, TSP); $50 \mathrm{~kg} \mathrm{~K}_{2} \mathrm{O} / \mathrm{ha}$ (in the form of muriate of potash, MP); $20 \mathrm{~kg} \mathrm{~S} / \mathrm{ha}$ (in the form of zypsum) and $1.5 \mathrm{~kg} \mathrm{Mo} / \mathrm{ha}$ (in the form of sodium molybdate) were applied to the pots during final pot media preparation. No nitrogen fertilizer was used in the experiment. Five germinated seeds were sown in each pot. Liquid rhizobial inoculants were prepared in the Soil Microbiology Laboratory of the Bangabandhu Sheikh Mujibur Rahman Agricultural University, Gazipur using YEM broth. Liquid inoculants were spread on the germinated seeds and were incorporated in soil.

Two healthy plants per pot were retained after the formation of first trifoliate leaf. All the intercultural operations like weeding, irrigation and drainage, mulching etc. were performed as and when necessary. Plant samples were collected from the pot at 50\% flowering stage (50 days after sowing, DAS) of the crops. Plants were carefully uprooted with the help of 'khurpi' so that no nodules were left in the soil. The roots were washed thoroughly with water. The nodules from the roots of each plant were separately collected and counted. The shoot root and nodules materials were first air-dried and then over dried at $65^{\circ} \mathrm{C}$ for $72 \mathrm{~h}$. Then oven-dried weight of shoot, root and nodule were recorded. The oven dried plant shoot material was ground in a grinding machine (Wiley Pulverizer, Type 1029-8, Yoshida Seisakusho Co Ltd, Japan). Total $\mathrm{N}$ content in the shoot material was determined by ashing the plant material using salicylic acid modified Kjeldahl method following sulphuric acid digestion and then colorimetric assay ${ }^{14}$. Nitrogen uptake by shoot was calculated from the data on dry matter yield and nitrogen content in shoot material of the crop. The recorded data of various characters of the crop were statistically analyzed to find out the significance of variation resulting from the experimental treatments. For this purpose, analysis of variance was worked out for each character of the crop. The difference between treatments means were compared by Duncan's Multiple Range Test (DMRT).

\section{Results and Discussion}

\section{Growth on Congo red YEM agar}

In general colonies of rhizobial isolates absorbed very little of the Congo red dye. Results presented in Table 1 show that Rhizobium isolates $R_{1}$ and $R_{6}$ absorbed the dye very weakly, while isolates $\mathrm{R}_{2}, \mathrm{R}_{3}, \mathrm{R}_{4}$ and $\mathrm{R}_{5}$ exhibited weak absorption of the dye. This result is consistent with that of Trinick ${ }^{15}$ who reported that rhizobia absorbed the dye weekly compared with other bacteria.

\section{Growth on peptone glucose agar}

Growth in peptone glucose agar as reported by Vincent ${ }^{16}$ indicates that most of the Rhizobium isolates grow either poorly or moderately in this medium. Isolate $R_{2}$ showed poor growth on the medium. Isolates $\mathrm{R}_{1}, \mathrm{R}_{3}, \mathrm{R}_{4}$ and $\mathrm{R}_{5}$ showed moderate growth on the medium. However, strain $\mathrm{R}_{6}$ did not grow at all in this medium (Table 1 ).

\section{Colony characteristics on YEM agar}

Rhizobium isolates are classified as fast- and slow-growing depending on growth on YEM agar. Isolates $R_{1}, R_{3}, R_{4}$ and $R_{5}$ were found to be fast-growing on YEM agar. These isolates produced large confluent colonies with abundant gum in YEM agar after 5 to 7 days of incubation. In contrast, isolates $R_{2}$ and $R_{6}$ showed slow growth in this medium (Table 1 ). Colonies of these isolates on YEM agar appeared small and separate with slight gum production. The texture of the sum was usually sticky.

\section{Acid/alkali production in YEM agar medium containing bromothymol blue indicator}

The importance of production of acid or alkali by the various rhizobia as reported by Norris ${ }^{13}$ has been emphasized when considering Rhizobium taxonomy. In this study, all the fast-growing Rhizobium isolates showed acidic reactions throughout their four weeks of growth, while all the slow-growing Rhizobium isolates started with an alkaline reaction after one week of growth (Table 1). It was observed that the isolates $\mathrm{R}_{1}, \mathrm{R}_{3}, \mathrm{R}_{4}$ and $\mathrm{R}_{5}$ produced acidic reaction on this medium. These isolates turned green colour of the medium to yellow. Isolates $\mathrm{R}_{2}$ and $\mathrm{R}_{6}$ produced alkali on this medium, which turned green colour of the medium to blue. 
Table 1. Characteristics of some Rhizobium strains isolated from nodules of pea

\begin{tabular}{lccccc}
\hline $\begin{array}{l}\text { Rhizobium } \\
\text { isolate }\end{array}$ & $\begin{array}{c}\text { Growth on } \\
\text { Congo red } \\
\text { YEM agar } \\
\text { (Absorption of dye) }\end{array}$ & $\begin{array}{c}\text { Growth on } \\
\text { peptone glucose } \\
\text { agar }\end{array}$ & $\begin{array}{c}\text { Colony } \\
\text { characteristics } \\
\text { on YEM agar } \\
\text { (Fast/slow) }\end{array}$ & $\begin{array}{c}\text { Acid/alkali } \\
\text { production in } \\
\text { YEM agar medium } \\
\text { containing BTB }\end{array}$ & $\begin{array}{c}\text { Growth in } \\
\text { YEM broth }\end{array}$ \\
\hline $\mathrm{R}_{1}$ & Slight & Moderate & Fast & Acid & Moderate turbidity \\
$\mathrm{R}_{2}$ & Weak & Poor & Slow & Alkali & Moderate turbidity \\
$\mathrm{R}_{3}$ & Weak & Moderate & Fast & Acid & Moderate turbidity \\
$\mathrm{R}_{4}$ & Weak & Moderate & Fast & Acid & Moderate turbidity \\
$\mathrm{R}_{5}$ & Weak & Moderate & Fast & Acid & Moderate turbidity \\
$\mathrm{R}_{6}$ & Slight & Nil & Slow & Alkali & Moderate turbidity \\
\hline
\end{tabular}

YEM = Yeast extract mannitol; BTB $=$ Bromothymol blue indicator.

\section{Growth in YEM broth}

Results reported in Table 1 indicate that Rhizobium isolates showed visible turbidity in YEM broth after 5 to 7 days of incubation. All the isolates produced moderate turbidity in this medium. The differences in texture of extracellular polysaccharide of the fast- and slow-growing rhizobia have been shown to be due to differences in monosaccharide comparison ${ }^{17}$.

\section{Number of nodules per plant}

The effect of Rhizobium inoculation on number of nodules per plant of pea was significant (Table 2). Plant inoculated with Rhizobium strains produced significantly higher number of total and effective nodule as compared to that of uninoculated control. Solaiman and Rabbani ${ }^{9}$ observed that pea inoculated with Rhizobium inoculant produced the highest number of nodules at pre-flowering and pod filling stages. The highest number of effective and total (70.50 and 92.75) nodule was obtained with isolate $\mathrm{R}_{3}$. The second highest number of total and effective nodule was obtained with isolate $\mathrm{R}_{5}$, which was statistically similar to the effect of isolates $R_{6}$ and $R_{4}$. The lowest number of nodule was obtained with the isolate $\mathrm{R}_{2}$, which was statistically similar to the effect of isolate $\mathrm{R}_{1}$.

Table 2. Effect of Rhizobium inoculation on number and dry weight of nodules of pea

\begin{tabular}{|c|c|c|c|c|}
\hline \multirow[t]{2}{*}{$\begin{array}{l}\text { Inoculation } \\
\text { treatment }\end{array}$} & \multicolumn{2}{|c|}{$\begin{array}{c}\text { No. of nodules/ } \\
\text { plant }\end{array}$} & \multicolumn{2}{|c|}{$\begin{array}{c}\text { Dry weight of nodules } \\
\text { (mg/plant) }\end{array}$} \\
\hline & Effective & Total & Effective & Total \\
\hline Control & $00.00^{\mathrm{d}}$ & $00.00^{\mathrm{e}}$ & $00.00^{C}$ & $00.00^{\mathrm{c}}$ \\
\hline $\mathrm{R}_{1}$ & $26.00^{c}$ & $39.00^{\mathrm{cd}}$ & $80.80^{\mathrm{b}}$ & $102.50^{\mathrm{b}}$ \\
\hline $\mathrm{R}_{2}$ & $19.00^{c}$ & $28.00^{\mathrm{d}}$ & $92.99^{b}$ & $114.39^{b}$ \\
\hline $\mathrm{R}_{3}$ & $70.50^{\mathrm{a}}$ & $92.75^{\mathrm{a}}$ & $140.34^{\mathrm{a}}$ & $176.72^{\mathrm{a}}$ \\
\hline $\mathrm{R}_{4}$ & $35.75^{\text {bc }}$ & $55.75^{\text {bc }}$ & $75.95^{\mathrm{b}}$ & $98.35^{\mathrm{b}}$ \\
\hline $\mathrm{R}_{5}$ & $48.75^{b}$ & $71.75^{\mathrm{b}}$ & $130.20^{\mathrm{a}}$ & $167.39^{\mathrm{a}}$ \\
\hline $\mathrm{R}_{6}$ & $35.25^{b c}$ & $59.00^{\mathrm{bc}}$ & $150.00^{\mathrm{a}}$ & $182.43^{\mathrm{a}}$ \\
\hline CV (\%) & 13.69 & 15.71 & 12.78 & 14.33 \\
\hline
\end{tabular}

Means in a column followed by same letter(s) are not significantly different at $5 \%$ level by DMRT.

\section{Dry weight of nodule}

There was a significant variation in dry weight of nodule per plant of pea with different Rhizobium isolates (Table 2). Plants inoculated with isolate $\mathrm{R}_{6}$ produced the highest dry weight of effective and total (150.00 and $182.43 \mathrm{mg} /$ plant) nodule, which was statistically similar to the effect of the isolates $R_{3}$ and $R_{5}$. The lowest dry weight of total nodule was obtained with the isolate $R_{4}$ whose effect was statistically similar to $R_{1}$ and $R_{2}$. This result was in agreement with Solaiman and Rabbani ${ }^{8}$ who reported that Rhizobium inoculant significantly increased dry weight of nodules per plant in edible-podded pea. There was a positive correlation between the number and dry weight of nodules $(r=0.907)$.

\section{Plant height}

The plant height of pea was significantly influenced by different treatments (Table 3). The highest plant height $(44.75 \mathrm{~cm})$ was recorded with the isolate $\mathrm{PR}_{3}$, which was statistically similar to the isolates $R_{4}, R_{1}$ and $R_{2}$. The lowest plant height was obtained in uninoculated control. This result resembles with that of Hossain and Solaiman ${ }^{18}$ who stated that plant height of mungbean increased significantly due to inoculation seeds with Rhizobium isolates.

Table 3. Effect of Rhizobium inoculation on plant height, root length, dry weight of shoot and root of pea

\begin{tabular}{lcccc}
\hline $\begin{array}{l}\text { Inoculation } \\
\text { treatment }\end{array}$ & $\begin{array}{c}\text { Plant } \\
\text { height } \\
(\mathrm{cm})\end{array}$ & $\begin{array}{c}\text { Root } \\
\text { length } \\
(\mathrm{cm})\end{array}$ & $\begin{array}{c}\text { Dry weight } \\
\text { of shoot } \\
(\mathrm{mg})\end{array}$ & $\begin{array}{c}\text { Dry weight } \\
\text { of root } \\
(\mathrm{mg})\end{array}$ \\
\hline Control & $24.50^{\mathrm{c}}$ & $16.25^{\mathrm{b}}$ & $1293.00^{\mathrm{d}}$ & $165.00^{\mathrm{b}}$ \\
$\mathrm{R}_{1}$ & $39.50^{\mathrm{ab}}$ & $21.50^{\mathrm{a}}$ & $1592.00^{\text {bcd }}$ & $507.50^{\mathrm{a}}$ \\
$\mathrm{R}_{2}$ & $39.00^{\mathrm{ab}}$ & $24.50^{\mathrm{a}}$ & $1950.00^{\mathrm{abc}}$ & $497.50^{\mathrm{a}}$ \\
$\mathrm{R}_{3}$ & $44.75^{\mathrm{a}}$ & $22.75^{\mathrm{a}}$ & $2003.00^{\mathrm{ab}}$ & $625.00^{\mathrm{a}}$ \\
$\mathrm{R}_{4}$ & $41.25^{\mathrm{a}}$ & $24.25^{\mathrm{a}}$ & $2210.00^{\mathrm{a}}$ & $437.50^{\mathrm{a}}$ \\
$\mathrm{R}_{5}$ & $33.75^{\mathrm{b}}$ & $23.50^{\mathrm{a}}$ & $1538.00^{\mathrm{cd}}$ & $540.00^{\mathrm{a}}$ \\
$\mathrm{R}_{6}$ & $32.75^{\mathrm{b}}$ & $25.50^{\mathrm{a}}$ & $1645.00^{\text {bcd }}$ & $550.00^{\mathrm{a}}$ \\
\hline $\mathrm{CV}(\%)$ & 10.93 & 14.48 & 13.64 & 15.49 \\
\hline
\end{tabular}

Means in a column followed by same letter(s) are not significantly different at $5 \%$ level by DMRT

\section{Root length}

There was no significant difference among the strains in recording root length of pea (Table 3). However, all the strains produced higher root length compared to uninoculated control. The highest root length $(25.50 \mathrm{~cm})$ was obtained with the strain $\mathrm{R}_{6}$ and the lowest root length was obtained with uninoculated control. This result was in agreement with Hossain and Solaiman ${ }^{18}$. 


\section{Dry weight of shoot}

It was noted that dry weight of shoot was influenced by Rhizobium inoculation (Table 3). The highest dry weight of shoot (2210 mg/ plant) was recorded with $\mathrm{PR}_{4}$, which was statistically similar with the isolates $R_{3}$ and $R_{2}$. Dry weight of shoot recorded with isolate $\mathrm{R}_{4}$ was $70 \%$ higher than that of uninoculated control. The lowest dry weight of shoot was recorded with uninoculated control. This result supports the findings of Solaiman and Rabbani ${ }^{6}$ who reported that Rhizobium inoculant significantly increased dry weight of shoot per plant in pea.

Dry weight of root

It is evident (Table 3) that there was no significant difference among the isolates in recording dry weight of root of pea. However, all the isolates produced higher dry wt of root compared to uninoculated control. The highest dry weight of root $(625 \mathrm{mg} /$ plant) was recorded with the isolate $R_{3}$ and the lowest was obtained from uninoculated control. Solaiman and Rabbani ${ }^{6}$ reported that Rhizobium inoculant significantly increased dry weight of root per plant of pea.

\section{Nitrogen $(N)$ content in shoot}

The performance of Rhizobium strains in recording $\mathrm{N}$ content in shoot was statistically different (Table 4). The highest $\mathrm{N}$ content (3.77\%) in shoot was obtained with the isolate $\mathrm{PR}_{6}$, which was statistically similar to that obtained with the isolates $R_{5}$ and $R_{3}$. Solaiman and Rabbani ${ }^{6}$ reported that Rhizobium inoculant significantly increased $\mathrm{N}$ content in shoot per plant of pea. The lowest $\mathrm{N}$ content in shoot was obtained from uninoculated control.

Table 4. Effect of Rhizobium inoculation on nitrogen $(N)$ content in shoot and nitrogen $(N)$ uptake by shoot of pea

\begin{tabular}{lcc}
\hline Inoculation treatment & $\begin{array}{c}\text { N content in } \\
\text { shoot }(\%)\end{array}$ & $\begin{array}{c}\text { N uptake by shoot } \\
\text { (mg/plant) }\end{array}$ \\
\hline Control & $1.70^{\mathrm{c}}$ & $22.00^{\mathrm{d}}$ \\
$\mathrm{R}_{1}$ & $2.27^{\mathrm{b}}$ & $36.26^{\mathrm{c}}$ \\
$\mathrm{R}_{2}$ & $2.60^{\mathrm{b}}$ & $50.77^{\mathrm{b}}$ \\
$\mathrm{R}_{3}$ & $3.21^{\mathrm{a}}$ & $64.34^{\mathrm{a}}$ \\
$\mathrm{R}_{4}$ & $1.25^{\mathrm{c}}$ & $27.57^{\mathrm{c}}$ \\
$\mathrm{R}_{5}$ & $3.25^{\mathrm{a}}$ & $49.98^{\mathrm{b}}$ \\
$\mathrm{R}_{6}$ & $3.77^{\mathrm{a}}$ & $62.08^{\mathrm{a}}$ \\
\hline $\mathrm{CV}(\%)$ & 11.52 & 12.43 \\
\hline
\end{tabular}

Means in a column followed by same letter(s) are not significantly different at $5 \%$ level by DMRT

\section{Nitrogen uptake by shoot}

The highest $\mathrm{N}$ uptake (62.08 $\mathrm{mg} / \mathrm{plant}$ ) was recorded with the strain $\mathrm{PR}_{3}$, which was statistically similar to that of $\mathrm{PR}_{6}$ (Table 4). All the isolates performed better than uninoculated control in respect of $\mathrm{N}$ uptake by shoot. This result was in agreement with that of Solaiman and Rabbani ${ }^{6}$ who reported that Rhizobium inoculant significantly increased $\mathrm{N}$ uptake by shoot in pea. The lowest $\mathrm{N}$ uptake by shoot was recorded from uninoculated control.
The present study demonstrates that two Rhizobium isolates, namely $R_{3}$ and $R_{5}$, had significant positive effective on nodule formation and nitrogen fixation in pea. High positive correlations also observed with respect to the number and dry weight of nodules, nitrogen content and uptake by shoot of pea.

\section{References}

1. Anonymous. 2004. Yearbook of Agricultural Statistics of Bangladesh, 2001, p 62. Bangladesh Bureau of Statistics, Ministry of Planning, Government of the People's Republic of Bangladesh, Dhaka.

2. Rana KS \& Sharma SK. 1993. Effect of rabi legumes on nitrogen economy and productivity of direct seeded upland rice. Crop Res Hisar. 6(1): 165-167.

3. Solaiman ARM \& Rabbani MG. 2003. Performance of pea as affected by Rhizobium inoculant, N, P, K and Mo application. Bangladesh $J$ Soil Sci. 27-29: 13-22.

4. Solaiman ARM, Hossain D \& Haque MM. 2003. Response of mungbean varieties to Rhizobium inoculation in respect of nodulation, nitrogenase activity, dry matter yield, and nitrogen uptake. Korean $J$ Crop Sci. 48(5): 355-360.

5. Solaiman ARM, Mahmud MS \& Hoque MS. 2003. Response of lentil to Rhizobium inoculant and nitrogen: Yield and yield contributing characters. Bangladesh J Life Sci. 15(2): 71-77.

6. Solaiman ARM \& Rabbani MG. 2004. Effects of Rhizobium inoculant and nitrogen application on pea. Bangladesh J Microbiol. 21(1): 36-41.

7. Rabbani MG, Solaiman ARM, Hossain KM \& Hossain T. 2005. Effects of Rhizobium inoculant, nitrogen, phosphorus and molybdenum on nodulation, yield, and seed protein in pea. Korean J Crop Sci. 50(2): 112-119.

8. Solaiman ARM \& Rabbani MG. 2005. Effects of Rhizobium inoculant, compost, and nitrogen on edible-podded pea. Bangladesh J Microbiol. 22(1): 5-9.

9. Solaiman ARM \& Rabbani MG. 2006. Effects of Rhizobium inoculant, compost, and nitrogen on nodulation, growth, and yield of pea. Korean J Crop Sci. 51(6): 534-538.

10. Solaiman ARM, Molla MN \& Hossain MD. 2006. Response of chickpea to dual inoculation with Rhizobium and arbuscular mycorrhiza, nitrogen and phosphorus. Korean J Crop Sci. 51(6): 527-533.

11. Khondaker M, Solaiman ARM, Karim AJMS \& Hussain MM. 2003. Responses of pea varieties to Rhizobium inoculation: Nitrogenase activity, dry matter production, and nitrogen uptake. Korean J Crop Sci. 48(5): 361-368.

12. Solaiman ARM \& Khondaker M. 2002. Response of some pea varieties to Rhizobium inoculation:yield attributes, yield and nutrient content in seed. Bangladesh J Microbiol. 19(1\&2): 41-46.

13. Noris DO. 1965. Acid predication of Rhizobium. A unifying concept. Plant Soil. 22: 143-166.

14. Cataldo DA, Schrader IE \& Young VI. 1974. Analysis by digestion and colorimetric assay of total nitrogen in plant tissues high in nitrate. Crop Sci. 14: 854-856.

15. Trinick MJ. 1982. Biology. In Nitrogen Fixation (Broughton WJ ed), Vol 2: Rhizobium, pp 76-146. Clarendon Press, Oxford.

16. Vincent JM. 970. A Manual for the Practical Study of Root Nodule Bacteria. Blackwell Scientific Publication, Oxford.

17. Bailey RW, Greenwood RM \& Craig A. 1971. Extracellular polysaccharides of Rhizobium strains associated with Lotus species. J Gen Microbiol. 65: 315-324.

18. Hossain D \& Solaiman ARM. 2004. Performance of mungbean varieties as affected by Rhizobium inoculants. Bull Inst Trop Agric Kyushu Univ. 27: 35-43. 